\title{
An Examination of the Teaching Methods for Entrepreneurship at a South African University
}

\author{
Olawale Fatoki
}

\author{
Department of Business Management, Turfloop campus, University of Limpopo, \\ Limpopo Province, South Africa Email: Olawale.fatoki@ul.ac.za
}

\section{Doi:10.5901/mjss.2014.v5n23p512}

\begin{abstract}
Entrepreneurship education is one the ways to improve the relatively low levels of entrepreneurship in South Africa. The objective of the study was to identify the traditional and non-traditional pedagogies employed for the teaching of entrepreneurship at a South Africa university. The study adopted a quantitative research approach with a descriptive design. The study focused on the final year students (undergraduate and postgraduate levels) in the Department of Business Management at a selected University located in the Limpopo Province of South Africa. Data was collected through the use of self-administered questionnaire in a survey. The results indicated that students perceive both the traditional and the nontraditional teaching methods as important to the development of their entrepreneurship skills and knowledge. In addition, the results indicated that students are mainly exposed to the traditional teaching methods. There is the need for an educational model that gives teachers the skills to combine the traditional teaching methods with the innovative methods through course design and content.
\end{abstract}

Keywords: teaching methods, entrepreneurship, university, South Africa

\section{Introduction}

The level of entrepreneurship is relatively low in South Africa. Herrington and Kew (2014) and Amoros and Bosma (2014) point out that the Total Entrepreneurial Activity (TEA) measures individuals and the level of early-stage entrepreneurs that are in the process of starting or that have just started a business. The TEA measures both nascent entrepreneurs (entrepreneurs that have not paid salaries or wages for more than three months) and new entrepreneurs (entrepreneurs that have paid salary and wages for more than three months but less than forty two months). South Africa's current TEA rate is $10.6 \%$. This is made up of nascent entrepreneurs $6.6 \%$ and new entrepreneurs $4.1 \%$. South Africa's TEA rate has improved since 2001 when it was $9.4 \%$. However, it is still significantly below the TEA of other African countries that participated in the Global Entrepreneurship Monitor survey in 2013. In addition, the number of potential entrepreneurs is relatively low. Potential entrepreneurs can be described as those that see opportunities in the environment, have the capacity to start a business and are not discouraged by failure. South Africa's perceived opportunities and capabilities have increased significantly by $92 \%$ and $40.5 \%$ respectively between 2001 and 2013 . However, it is only about one-third of other African countries. One of the reasons for the relatively low levels of perceived opportunities and capabilities in South Africa is the relatively low perception of skills to start a business. The number of intentional entrepreneurs is also relatively low. Intentional entrepreneurs can be described as those who intend to start a business in the next three years. South Africa's rate of perception that entrepreneurship is a good career has increased by 54\% between 2001 and 2013. However, it is still below that of other African countries. Also, the rate of potential youth entrepreneurs in South Africa is significant below the average for other African countries.

Entrepreneurship education is one the ways to improve the relatively low levels of Total Entrepreneurial Activity and potential and intentional entrepreneurs in South Africa. Gerba (2012) observes that fostering entrepreneurship has become a topic of highest priority in public policy. Matlay (2006) notes that entrepreneurship education is believed by policy makers to result in growth in the quantity and quality of entrepreneurial activity. According to Sardeshmukh and Smith-Nelson (2011), there is the need to provide the kind of education that is needed to develop an opportunity-oriented entrepreneurial mind-set among tertiary students. In addition, employers want graduates that are entrepreneurially minded. Lourenco et al. (2013) point out that the development of an entrepreneurial mind-set and/or enterprising skills is on the agenda for developing graduates in order to enhance their employability. Employers are looking for graduates that are equipped with skills that will enable them to act in enterprising ways so they can deal effectively with a difficult business environment, and a personal life that is increasingly full of uncertainties and complexities. 
Kirby (2002), Blenker et al. (2006) and Shambare (2013) remark that teaching methods that improves an individual's knowledge and skills is positively associated with increased entrepreneurial motivation, innovation, and the capability and understanding of how to start and sustain a new venture. Inappropriate teaching methods will negatively impact on the outcomes of entrepreneurship education. Peterman and Kennedy (2003) and Pihie and Sani (2009) note that it is important to develop a teaching program that will develop capable and skilled entrepreneurs. According to Mwasalwiba (2010), the two primary teaching methods for entrepreneurship are the traditional (passive) and the nontraditional (active) methods. An efficient combination of the two primary teaching methods will improve entrepreneurship education. The application of different pedagogical methods in entrepreneurship classrooms can assist student in developing entrepreneurial skills (Neck and Greene, 2011). Most of the studies on the effectiveness of entrepreneurship education have focused on the viewpoint of academics, however, it is important to obtain the perception of students (Gerba, 2012). This study extends the study by Fatoki and Oni (2014) on entrepreneurship education in South Africa.

\section{The Objective of the Study}

An efficient combination of teaching methods will improve entrepreneurship education. Entrepreneurship education is one the ways to improve the relatively low levels of entrepreneurship in South Africa. The objective of the study is to identify the traditional and non-traditional pedagogies employed for the teaching of entrepreneurship at a South Africa university.

\section{Literature Review}

\subsection{The meaning of entrepreneurship education}

Shane and Venkataranam (2000) point out that one of the biggest obstacles in creating a conceptual framework for the field of entrepreneurship is its definition. Most researchers have tended to define entrepreneurship solely in the context of who is an entrepreneur and what does an entrepreneur do. However, entrepreneurship involves two phenomena. (1) The presence of lucrative opportunities and (2) the presence of enterprising individuals. Thus the field of entrepreneurship involves "the study of sources of opportunities; the processes of discovery, evaluation, and exploitation of opportunities; and the set of individuals who discover, evaluate, and exploit them". Foss and Klein (2010) point out that entrepreneurship is the act of grasping and responding to profit opportunities that exist in an imperfect world.

According to Henry et al. (2005) and Solomon (2007), there is a considerable uncertainty in the field of entrepreneurship as to whether entrepreneurs are born or made. This has led to an ongoing debate in the entrepreneurship academy about whether individuals can be taught entrepreneurship. Adcroft et al. (2004) argue that entrepreneurs cannot be manufactured but only recognised. This suggests that entrepreneurship cannot be taught. Drucker (1985) points out that entrepreneurship is a discipline and, like any discipline, it can be learned. Kuratko (2003) points out that the question of whether entrepreneurship can be taught is obsolete. Entrepreneurship can be taught or at least encouraged by entrepreneurship education. Lee et al. (2005) ascertain that entrepreneurship education provides students with the motivation, knowledge, and skills that are essential for launching a successful venture. This suggests that entrepreneurial talents can be "matured-up" by education. Lorenco and Jones (2006) point out that there is now a consensus in the literature that entrepreneurship can be taught and the debate has now shifted to what and how it should be taught. Current evidence however seems to suggest that there is a gap between the perceived desirability of entrepreneurship amongst students and actual self-employment and start-up rates amongst graduates. This has focused attention on the impact of entrepreneurship education. The nature, relevance and appropriateness of entrepreneurship education have been subject to increasing scrutiny (Lee and Wong 2005). According to Arasti et al. (2012), the key to a successful entrepreneurship education is to find the most effective way to manage the teachable skills and identify the best match between student needs and teaching techniques.

Garba (2012) asserts that the term "entrepreneurship education" has been defined in several ways in entrepreneurship literature. Shepherd and Douglas (1997) propose that "The essence of entrepreneurship education is the ability to envision and chart a course for a new business venture by combining information from the functional disciplines and from the external environment in the context of the extraordinary uncertainty and ambiguity which faces a new business venture. It manifests itself in creative strategies, innovative tactics, uncanny perception of trends and market mood changes, courageous leadership when the way forward is not obvious and so on. What we teach in our entrepreneurship classes should serve to instil and enhance these abilities".

Alberti et al. (2004) define entrepreneurship education as "the structured formal conveyance of entrepreneurial competencies, which in turn refers to the concepts, skills, and mental awareness used by individuals during the process 
of starting and developing their growth oriented ventures. Entrepreneurship education aims at building entrepreneurial competencies, which are considered as combinations of the different skills, knowledge and attitudes"

Henry et al. (2005) point out that the two important objectives of entrepreneurship education programmes are (1) to increase the awareness and understanding of the process involved in initiating and managing a new business, and (2) to increase students' awareness of small business ownership as a serious career option. Frank et al. (2005) agree that entrepreneurship education aims at creating or increasing entrepreneurial attitudes, spirit and culture among individuals and in the general community. Entrepreneurship education is associated with opportunity recognition, venture creation and growth. This is consistent with the view of Klein and Bullock (2006) that entrepreneurship education should include the management of existing resources, the acquisition new resources, the identification of existing opportunities and the creation new opportunities

Souitaris et al. (2007) find that entrepreneurship programs significantly raise students' subjective norms and intentions toward entrepreneurship by inspiring them to choose entrepreneurial careers. According to Ismail et al. (2009), entrepreneurial education at tertiary level has also become an essential component of many curriculums in higher learning institutions. Since future entrepreneurs can be found amongst those who are currently undergoing their educational process at the universities, entrepreneurship education has been used as one of the most effective ways to promote the transition of graduates into the world of entrepreneurship. The Consortium of Entrepreneurship Education (2013) observes that entrepreneurship education seeks to prepare people, especially youth, to be responsible, enterprising individuals who become entrepreneurs or entrepreneurial thinkers and who contribute to economic development and sustainable communities. Entrepreneurship education is not only about teaching how to run a business, it is also about encouraging creative thinking and promoting a strong sense of self-worth and accountability. Through entrepreneurship education, students learn how to create a business, but they also learn a lot more. The core knowledge created via entrepreneurship education includes: the ability to recognize opportunities in one's life; the ability to pursue such opportunities by generating new ideas and marshalling needed resources; the ability to create and operate a new venture and the ability to think in a creative and critical manner.

\subsection{Methods of teaching entrepreneurship}

Blenker et al. (2006) point out that because there is no single clear-cut definition of entrepreneurship, therefore there is no unequivocal agreement by researchers on what should be the objectives of the teaching and learning processes. Mwasalwiba (2010) remarks that although it is not a hard decision for universities to run courses in entrepreneurship, however, it is a challenge to academicians to choose the teaching methods that align to their course objectives, environments and even the type of students in the program. One of the major issues in entrepreneurship is how it should be taught. Desai et al. (2010) ascertain that there are four objectives for the teaching of entrepreneurship. These are (1) increase awareness and understanding of new venture process; (2) introduce entrepreneurship as an option of career; (3) understand functional business relationships, and (4) recognize or understand traits and characteristics of entrepreneurs. The teaching methods should take into consideration these objectives.

Mwasalwiba (2010) and Tasnim (2012) note that the teaching methods for entrepreneurship can be classified into two. (1) The traditional (passive) methods which comprise normal lectures, seminars, reading, business plan, project works. (2) The non-traditional, innovative methods (active) methods which are more action-based. Innovative teaching methods seek to improve students' creativity and analytic way of problem solving. The active methods expect the teacher to facilitate learning, not to control and apply methods that enable students' self-discovery. Innovative teaching methods include computer simulations that can provide students with experiences of simulated new venture decision making and develop their skills in complex decision-making. Other non-traditional teaching methods include visits and attachments to companies to gain practical experience (Solomon, 2007), (Balan, 2014).

Mousa (2014) points out that higher education is currently witnessing a widespread change in the approaches to teaching and curriculum from traditional lecturing to innovative methods. The drivers for such change include the realisation that traditional teaching methods are relatively ineffective for many students, the changing nature of work and knowledge, and the emergence of new information and communication technologies. Universities are now considered one of the hubs for economic development worldwide. Technological advancement and large-scale problems need sophisticated problem solving skills. Innovative and complicated solutions are very important for the success of entrepreneurial program. Mwasalwiba et al. (2010) agree that the traditional methods are less effective in encouraging entrepreneurial attributes and make students become dormant participants. These methods prepare a student to work for an entrepreneur, but not to become one. Traditional methods should only be used to give students the commercial underpinnings of their entrepreneurial actions. However, entrepreneurship involves doing something practical and having 
an opportunity to question, investigate, converse, and discuss with real-world entrepreneurs gives both knowledge and skills and also stimulates attitudes. However, in a practical sense most of the advocated active/action-based teaching methods are costly and somehow may not align to the conventional university system of teaching

Lourenço and Jones (2006) point out that the criticisms of the traditional mode of teaching entrepreneurship have led to the second mode that can be described as the enterprise mode (learning by doing) based on the cognitive learning model. Under the enterprise mode, learning is a dynamic, constructive and goal-orientated process rather than being passive. Learning is enhanced as students are engaged in the construction of knowledge by acquiring, generating, analysing, manipulating and structuring information. The enterprise mode uses a transformative methodology. This means that learners are engaged in constructing and owning their learning. The traditional approaches use a transmissive methodology for teaching and learning. This means that teaching is instructive and associated with the transfer of information. Bennet (2006) notes that non-traditional, active teaching methods require lecturers to facilitate learning thereby enabling self-discovery.

Laukkannen (2000) differentiates two areas of entrepreneurship education: (1) Education about entrepreneurship: This involves developing, constructing and studying the theories related to entrepreneurship and firm creation and the contribution of entrepreneurship to economic development (2) Education for entrepreneurship: This trains present and potential entrepreneurs on the entrepreneurial process, providing all the tools necessary for the start-up of a new venture both within and outside an existing organisation. Education about entrepreneurship is mainly based on the construct and transference of knowledge about the field, while education for entrepreneurship focuses on the learning experience and the development of competencies, skills, aptitudes and values. The teaching methods used for both areas of entrepreneurship education vary.

Hytti and O'Gorman (2004) argue that there are many ways to offer entrepreneurship education and this depends on the objectives of such education. If the objective of entrepreneurship education is to increase the understanding of what entrepreneurship is about, the best way to accomplish the objective is to provide information through public channels such as media, seminars, or lectures. However, if the objective is to equip individuals with entrepreneurial skills, which are applicable directly to work, the best way is to provide education and training that enable individuals to involve directly in the entrepreneurial process (i.e. through industrial training). In addition, if the objective of entrepreneurship education is to prepare individuals to act as entrepreneurs, the most effective technique is to facilitate experiments by trying entrepreneurship out in a controlled environment, for instance through business simulation or role playing.

\section{Research Methodology}

The study adopted a quantitative research approach with a descriptive design. The study focused on the final year students (undergraduate and postgraduate levels) in the Department of Business Management at a selected University located in the Limpopo Province of South Africa. These are students that have done entrepreneurship. The student population was 264. Raosoft sample size calculator gave a sample size of 157. However, 196 questionnaires were distributed in class to the students with the assistance of the lecturers. Data was collected through the use of selfadministered questionnaire in a survey. Participation in the survey was voluntary and confidentiality assured.The teaching methods investigated by the study were adapted from previous studies such as Pihie and Sani (2009) and Mwasalwiba (2010). The first part of the questionnaire on the teaching methods for entrepreneurship focused on students' perceived importance of both the traditional (passive) and non-traditional (active) teaching methods to the development of their entrepreneurship skills and knowledge. Five-point Likert scale questions ranging from "1. Very unimportant", "2 unimportant", "3 neither important nor unimportant", "4, important", "5 very important"' were used. The second part focused on the teaching methods that students are exposed to. Five-point Likert scale questions ranging from "1, never", "2, rarely", "3, sometimes", "4, frequently" and " 5 , always" were used. Reliability was measured using the Cronbach's alpha. Nunnally (1978) recommended a rule of thumb of 0.7 as the minimum acceptable coefficient. The study used descriptive statistics for data analysis.

\section{Results and Discussions}

196 questionnaires were distributed in class and 181 questionnaires were returned. The response rate was 92.3\%. 12 questionnaires were found unusable because of the failure of the respondents to complete vital parts of the questionnaire. 169 questionnaires were found usable. There were 73 male respondents and 96 female respondents. 


\subsection{Importance attached by students to teaching methods}

Table 1: Importance attached to teaching methods

\begin{tabular}{|l|c|c|}
\hline Teaching methods & Mean & Standard deviation \\
\hline Lectures & 4.88 & 1.05 \\
\hline Individual assignments & 3.48 & 0.97 \\
\hline Group assignments & 3.65 & 0.79 \\
\hline Presentations & 3.68 & 0.94 \\
\hline Seminars & 3.62 & 1.02 \\
\hline Case studies & 3.95 & 1.07 \\
\hline Research project & 3.45 & 0.88 \\
\hline Guest speaker and role models & 4.60 & 1.02 \\
\hline Video recorded & 3.30 & 0.71 \\
\hline Business simulations & 3.65 & 0.88 \\
\hline Business plan presentation & 4.78 & 1.04 \\
\hline Visit to businesses & 4.82 & 1.01 \\
\hline Attachment with a business & 4.85 & 1.04 \\
\hline Developing and running a venture & 4.25 & 0.89 \\
\hline
\end{tabular}

\subsection{Use of teaching methods}

Table 2: Teaching methods for entrepreneurship education

\begin{tabular}{|l|c|c|}
\hline Teaching methods & Mean & Standard deviation \\
\hline Lectures & 5.00 & 1.24 \\
\hline Individual assignments & 3.20 & 0.96 \\
\hline Group assignments & 3.15 & 0.94 \\
\hline Presentations & 2.85 & 0.75 \\
\hline Seminars & 1.08 & 1.20 \\
\hline Case studies & 2.25 & 0.87 \\
\hline Research project & 2.52 & 1.01 \\
\hline Guest speaker and role models & 1.12 & 1.04 \\
\hline Video recorded & 1.02 & 1.04 \\
\hline Business simulations & 1.02 & 1.07 \\
\hline Business plan presentation & 4.25 & 1.01 \\
\hline Visit to businesses & 1.02 & 0.99 \\
\hline Attachment with a business & 1.02 & 1.04 \\
\hline Developing and running a venture & 1.02 & 1.02 \\
\hline
\end{tabular}

The results as presented by table 1 indicate that students perceive both the traditional and the non-traditional teaching methods as important to the development of their entrepreneurship skills and knowledge. Students view lectures as highly important. The traditional methods of teaching entrepreneurship such as lectures provide students with education about entrepreneurship: Traditional methods help students to develop, construct and study the theories related to entrepreneurship and firm creation and the contribution of entrepreneurship to economic development. In addition, the business plan helps students to understand the entrepreneurial process. Traditional teaching methods are mainly based on the construct and transference of knowledge about the field, Students also view the non-traditional methods of teaching entrepreneurship such as visit to business, working for a business through industrial training, developing a venture whilst studying and inviting guest speakers as very important to the development of their entrepreneurship skills and knowledge. The results as presented in table 2 indicate that students are mainly exposed to the traditional teaching methods. Non-traditional teaching methods such as inviting guest speakers and business role models, business simulations and working for business to gain practical experience in how to run a business are rarely used. Nontraditional, innovative teaching methods can provide students with experiences of new venture decision making and develop their skills in complex decision-making. Mwasalwiba et al. (2010) point out that the traditional methods are less effective in encouraging entrepreneurial attributes and make students become dormant participants. These methods prepare a student to work for an entrepreneur, but not to become one. Entrepreneurship involves doing something practical and having an opportunity to question, investigate, converse, and discuss with real-world entrepreneurs gives 
both knowledge and skills and also stimulates attitudes. Neck and Greene (2011) remark that an efficient combination of the two primary teaching methods will improve entrepreneurship education. The application of different pedagogical methods in entrepreneurship classrooms can assist student in developing entrepreneurial skills. This is consistent with the view of Kolb (1984) in his book entitled Experiential Learning that experience is the one of the sources of learning and development. An individual learns through discovery and experience. According to Kolb, there are four stages in the learning cycle. These are concrete experience, reflective observation, abstract conceptualisation and active experimentation. The stages can be differentiated by the sources of information from which an individual form concept and principles and also by the mode of information processing. Pfeifer and Borozan (2011) point out that to make entrepreneurship education programs more effective, learners, teachers, and entrepreneurship education institutions can benefit from systematic understanding of the alternative ways of delivering complex content. Akinboye and Pihie (2014) remark that the goal of entrepreneurial learning is to bring about changes in the behaviour of learners. The learning style of students should play an important role in entrepreneurship course design in order to produce individuals with an enterprising culture. Therefore, individual learning preferences should be given adequate attention in entrepreneurship education curriculum development and pedagogy. This will make the course contents relevant to all learners.

\section{Conclusions}

Entrepreneurship education is one the ways to improve the relatively low levels of entrepreneurship in South Africa. An efficient combination of teaching methods will improve entrepreneurship education. The two primary teaching methods for entrepreneurship are the traditional (passive) and the non-traditional (active) methods. The objective of the study is to identify the traditional and non-traditional pedagogies employed for the teaching of entrepreneurship at a South Africa university. The results indicate that students perceive both the traditional and the non-traditional teaching methods as important to the development of their entrepreneurship skills and knowledge. In addition, the results indicate that students are mainly exposed to the traditional teaching methods. Non-traditional teaching methods such as inviting guest speakers and business role models, business simulations and working for business to gain practical experience in how to run a business are rarely used. There is the need for an educational model that gives teachers the skills to combine the traditional teaching methods with the innovative methods through course design and content. It is also important for entrepreneurship lecturers to invite guest speakers and role models to assist in the teaching of entrepreneurship. For instance, government organisations that have the mandate to assist entrepreneurs in South Africa include the Small Enterprise Finance Agency (SEFA) and the Small Enterprise Development Agency (SEDA). Experts from these organisations are better enabled to inform students about the sources of finance and advice that are available to entrepreneurs. These organisations should make student entrepreneurship as part of their strategic framework. The study was conducted at only one university. Thus, caution must be exercised in interpreting the findings and in making generalisations. Data collection could be expanded to include a larger sample from other universities in South Africa.

\section{References}

Adcroft, A., Willis, R., \& Dhaliwal, S. (2004). Missing the point? Management education and entrepreneurship. Management Decision, $42(3 / 4): 512$ $-521$

Akinboye, A.K., \& Pihie, ZAL (2014). Effects of learning styles on students" perceptions of entrepreneurship course relevance and teaching methods. International Interdisciplinary Journal of Education, 3(1): 217-224

Alberti, Fernando, Sciascia, Salvatore, Poli, Alberto (2004), Entrepreneurship Education: Notes on an Ongoing Debate. 14th Annual International Entrepreneurship Conference, University of Napoli Federico II (Italy), 4-7 July

Amorós, José Ernesto, Bosma, Niels (2014), Global entrepreneurship Monitor 2013 global report [Online] Available:. http://www.gemconsortium.org/docs/download/3106 (August 5, 2014)

Arasti, Z., Falavarjani, M.K., \& Imanipour, N. (2012). A study of teaching methods in entrepreneurship education for graduate students. Journal of Higher Education Studies, 2(1): 2-10.

Azim, M.T., \& Al-Kahtani, A.H.M. (2014). Entrepreneurship education and training: a survey of literature. Life Science Journal, 11(1): 127-135

Balan S.M (2014). Methods and means used in teaching entrepreneurship in high school can improve entrepreneurial skills. International Journal of Management, 5(7)51-61

Bennett, M. (2006). Business lecturers' perception of the nature of entrepreneurship. International Journal of Entrepreneurial Behaviour \& Research, 12(3): 165-88.

Blenker, Per, Dreisler, Poul, Kjeldsen, John (2006), Entrepreneurship education- the new challenge facing the universities. . [Online] Available: http://pure.au.dk//portal/files/32345606/2006-02_ENG.pdf (June 2, 2014)

Consortium of Entreprenuership Education (2013). Entrepreneurship Education. [Online] Available: http://www.entre-ed.org/ (February 9, 2013)

Desai, Sameeksha, Acs, Zoltan, Weitzel, Utz (2010), A Model of Destructive Entrepreneurship. United Nations University. World Institute for development economics research. Working paper no 2010/34 
Drucker P.F. (1985) Innovation and entrepreneurship, London: Pan Books Ltd.

Fatoki O., \& Oni, O. (2014). Students perception of the effectiveness of entrepreneurship education at a South African University. Mediterranean Journal of Social Sciences, 5(20):585-591.

Foss, Nicolai, Klein, Peter 2010. Alertness, action, and the antecedents of entrepreneurship. [Online] Available:http://web.missouri.edu/ kleinp/papers/10041.pdf_(May 9, 2014)

Frank, H., Korunka, C., Lueger, M., \& Mugler, J. (2005). Entrepreneurial orientation and education in Austrian secondary schools. Journal of Small Business and Enterprise Development, 12(2), 259-273.

Henry, C., Hill F., and Leitch C. (2005). Entrepreneurship Education and Training: Can Entrepreneurship be Taught? Part I. Education and Training, 47 (2): 98-107

Hytti, U., \& O'Gorman, C. (2004). What is "enterprise education"? An analysis of the objectives and methods of enterprise education programmes in four European countries", Education + Training, 46(1): 11 - 23

Gerba, D.T. (2012). Impact of entrepreneurship education on entrepreneurial intentions of business and engineering students in Ethiopia. African Journal of Economic and Management Studies, 3 (2): 258-277

Henry, C., Hill, F., \& Leitch C. (2005). Entrepreneurship education and training: can entrepreneurship be taught? Part I. Education and Training, 47 (2): 98-107

Herrington, Mike, Kew. Jacqui (2014), Global entrepreneurship monitor 2013 South African report. [Online] Available http://www.gemconsortium.org/docs/download/3336 (August 5, 2014)

Ismail, M., Khalid, S.A., Othman, M., Jusoff, K., Abdul Rahman, N., Mohammed, K.M., \& Shekh, R.Z. (2009). Entrepreneurial intention among Malaysian undergraduates. International Journal of Business and Management, 4(10): 54-60.

Klein, P. G., Bullock, J. B. (2006). Can entrepreneurship be taught? Journal of Agricultural and Applied Economics , 38 (2), $429-439$.

Kirby, D. (2002). Entrepreneurship education: can business schools meets the challenge. paper presented at the RENT Conference, Barcelona, November

Kolb, D.A. (1984). Experiential learning--experience as the source of learning and development, London, Prentice-Hall.

Kuratko, Donald (2003), Entrepreneurship education: emerging trends and challenges for the $21^{\text {st }}$ century. [Online] Available: http://www.unm.edu/ asalazar/Kauffman/Entrep_research/e_ed.pdf (May 18, 2014].

Laukkanen, M. (2000). Exploring alternative approaches in high-level entrepreneurship education: Creation micro mechanisms for endogenous regional growth. Journal of Entrepreneurship and Regional Development, 12: 25-47.

Lee, Lena, Wong, Poh (2005), Entrepreneurship education - a compendium of related issues. [Online] Available: http://papers.ssrn. com/sol3/papers.cfm?abstract_id=856227 (May 10, 2014)

Lee, S.M., Chang, D., \& Lim, S.B. (2005). Impact of entrepreneurship education: a comparative study of the U. S. and Korea. International Entrepreneurship and Management Journal, (1): 27-43.

Lourenço, F., Jones, O. (2006). Developing entrepreneurship education: comparing traditional and alternative teaching approaches. International Journal of Entrepreneurship Education, 4(1):111-140.

Lourenço, F., Taylor, T.G., \& Taylor, D.W. (2013).Integrating education for entrepreneurship in multiple faculties in "half-the-time" to enhance graduate entrepreneurship. Journal of Small Business \& Enterprise Development, 20(3): 503 - 525.

Matlay, H. (2006). Researching entrepreneurship and education: Part 2: what is entrepreneurship education and does it matter? Education + Training, 48 ( 8/9): $704-718$

Mokaya, S.O., Namusonge, M., \& Sikalieh, D. (2012). The concept of entrepreneurship; in pursuit of a universally acceptable definition. International Journal of Arts and Commerce, 1(6):128-135

Mousa, Wail, (2014), A Role Model Program for Innovation and Entrepreneurship. [Online] Available: http://www.ieche.com.sa/portal/en /2014/Seminars-168/A_Role_Model_Program_for_Innovation_and_Entrepreneurship (August 20, 2014)

Mwasalwiba, E.D (2010) Entrepreneurship education: a review of its objectives, teaching methods, and impact indicators", Education + Training, 52(1): $20-47$

Neck, H. M., \& Greene, P. G. (2011). Entrepreneurship Education: Known Worlds and New Frontiers. Journal of Small Business Management, 49(2), 55-70.

Nunnally, J.C (1978). Psychometric Theory, 2nd ed. New York: McGraw-Hill.

Peterman N.E., \& Kennedy J. (2003). Enterprise education: influencing students' perception of entrepreneurship. Entrepreneurship Theory \& Practice, 28(2): 129-144.

Pfeifer, S., \& Borozan, D. (2011). Fitting Kolb's learning style theory to entrepreneurship learning aims and contents. International Journal of Business Research, 11(2): 216-223

Pihie, Z.A.L., \& Sani, A.S.A. (2009). Exploring the entrepreneurial mind-set of students: implication for improvement of entrepreneurial learning at university. The Journal of International Social Research, 2(8): 340-345

Sardeshmukh, S.R., \& Smith-Nelson, R. (2011). Educating for an entrepreneurial career: developing opportunity recognition ability. Australian Journal of Career Development, 20(3): 47-55.

Shambare, R (2013). Barriers to Student Entrepreneurship in South Africa. Journal of Economics and Behavioural Studies, 5(7): 449-459

Shane, S., \& S Venkataraman. 2000. The Promise of Entrepreneurship as a Field of Research. The Academy of Management Review, 25(1): 217-226

Shepherd, Dean, Douglas, Evan (1997). Is management education developing, or killing, the entrepreneurial spirit? [Online] Available: http://www.researchgate.net/publication/2435925_Is_Management_Education_Developing_or_Killing_the_Entrepreneurial_Spirit (July 3, 2014)

Solomon, G. (2007). An examination of entrepreneurship education in the United States. Journal of Small Business and Enterprise Development, $14(2), 168-182$.

Souitaris, V., Zerbinati, S., Andreas, A. (2007). Do entrepreneurship programmes raise entrepreneurial intention of science and engineering students? The effect of learning, inspiration and resources. Journal of Business Venturing, 22(4): 566-591.

Tasnim N. 2012. Playing Entrepreneurship : Can Games Make a Difference? Entrepreneurial Practice Review, 2(4): 4-18. 